\title{
Agronomic fortification of zinc in potato production in Indian context: A review
}

\begin{abstract}
Sukamal Sarkar*
Department of Agronomy, Bidhan Chandra Krishi Viswavidyalaya, Mohanpur-741252 (West Bengal), India

Hirak Banerjee

Regional Research Station (CSZ), Bidhan Chandra Krishi Viswavidyalaya, Kakdwip-743347 (West Bengal), India

Kajal Sengupta

Department of Agronomy, Bidhan Chandra Krishi Viswavidyalaya, Mohanpur-741252 (West Bengal), India

*Correspondence author. E-mail: sukamalsarkarc@yahoo.com

Abstract

Micronutrient has received greater attention in crop production because the widespread deficiency of micronutrient is coming forward gradually. The key reasons for such deficiency are an intensification of cropping system, adoption of high yielding cultivars of crops and modern irrigation facilities. The greater use of high analysis chemical fertilizers instead of organic sources of plant nutrients (farmyard manure, composts etc.) is also another contributing factor to this problem. This modern technology of crop production causes a serious depletion of different micronutrients reserve in soil resulting in their severe deficiency in many countries. Potato is the widely cultivated vegetable crops throughout India. In potato cultivation, the application of some micro-nutrients (zinc/Zn, boron/B etc.) causes significant increase in foliage at the initial stage of crop growth, while the translocation of assimilates become higher in later stages, ultimately leads to higher yield. Zinc plays a very important role in increasing the production as well as the quality of potato tubers. Zinc loading in potato through foliar as well as soil-applied $\mathrm{Zn}$ increases $\mathrm{Zn}$ concentration in potato tuber up to 3-4 times which is quite higher than most of the commonly known crops. Zn fertilization has been found to increase ascorbic acid content, but it reduces the tyrosine and total phenol content in tubers, and thereby improves the processing quality. Finally, $\mathrm{Zn}$-fortified potato can be a potential option for mitigating wide spread $\mathrm{Zn}$-driven malnutrition in the Asian countries.
\end{abstract}

Keywords: Ferti-fortification, Solanum tuberosum, Tuber quality, Yield, Zinc

\section{INTRODUCTION}

Potato (Solanum tuberosum L.) ranks just behind the cereals rice and wheat, achieved $3^{\text {rd }}$ position among the food crops worldwide (Birch et al., 2012). Potato is a staple food for more than a billion people worldwide, and considered as a critical crop in terms of food security to combat population growth and increased hunger rates. Potato is one of the most important crops throughout India (Fig. 1). India now ranks $2^{\text {nd }}$ in potato production $(45.34 \mathrm{~m} \mathrm{t}$ ) after China (Fig. 2), but the productivity of the crop in India $\left(22.9 \mathrm{t} \mathrm{ha}^{-1}\right)$ is quite low compared to other leading potato growing countries in the world (FAOSTAT, 2015). Potato crop demands greater attention because of its exceptionally high productivity coupled with high food value. As compared to major cereal crops, potato produces more dry matter and protein per unit

\section{Article Info}

DOI:10.31018/jans.v10i3.1863

Received: August 5, 2018

Revised: August 23, 2018

Accepted: August 26, 2018

\section{How to Cite}

Sarkar, S. et al. (2018).

Agronomic fortification of zinc in potato production in Indian context: A review. Journal of Applied and Natural Science, 10(3): $1037-1045$ 
Sarkar, S. et al. / J. Appl. \& Nat. Sci. 10 (3): 1037 - 1045 (2018)

ferent micronutrients reserve in soil resulting in their severe deficiency in many areas of the country. Reports are there that potato plants require micronutrient to produce optimum yield (Murmu et al., 2014). In potato cultivation some minor plant nutrients like $\mathrm{Zn}$, B can help in increasing the foliage at initial stage of growth and in the later stages, the translocation of assimilates is responsible for higher yield (Trehan and Grewal, 1981; Mondal et al., 1993).

Low recovery of applied $\mathrm{Zn}$ is the main constraint in augmenting the yield of potato (Singh et al., 2014), which signifies the importance of $\mathrm{Zn}$ in potato cultivation. Depending upon the duration of variety, potato crop is highly sensitive to $\mathrm{Zn}$ application. Zn fertilization has been found to increase ascorbic acid content, but it reduces the tyrosine and total phenol content in tubers and thereby improves the processing quality (Mondal et al., 2015). Besides yield increase, micronutrients are also influencing the quality of potato by increasing protein content and some antioxidants. Antioxidant, scavengers of free radicals of our body due to oxidative stress, are known to be associated with ageing, heart disease mortality, incidence of cancer (mouth, pharynx and colon) and other degenerative diseases. Therefore, the key objective of this paper is to focus on the advantages of adopting zinc fertilization for the agronomic fortification of potato crop. In this paper, we compiled the specific role of zinc in plant growth vis-a-vis soil health improvement status by enhanced use of zinc-fertilizer and finally the implications for redesigning $\mathrm{Zn}$ fertilization practice in potato cultivation in terms of dose, time and method.

Zn deficient soils in India: Zinc deficiency is extensively reported on major soil types in India. The common basis for determination of $\mathrm{Zn}$ deficiency is soil and plant testing. In India, Nene (1966) while growing rice on an alkali soil first recognised zinc deficiency. The distribution of $\mathrm{Zn}$ deficient soils was further reviewed by Takkar (1991) by analysing more than 113,000 soil samples for available Zn (mostly DTPA extractable) and about 20,000 plant analyses from 15 states and territories in India, and he concluded that 44$46 \%$ soils are $\mathrm{Zn}$-deficient. The deficiency ranged between $60-70 \%$ in the states of Haryana, Madhya Pradesh and Uttar Pradesh; 50-59\% in Andhra Pradesh and Punjab; $30-49 \%$ in Kerala, Bihar and Tamil Nadu; 20-29\% in Delhi, Gujrat, Karnataka and Rajasthan, and less than $20 \%$ in Jammu and Kashmir and Pondicherry. He found the greater incidence of $\mathrm{Zn}$ deficiency in calcareous, coarse textured soils; in high water table as well as flood plain soils; and in saline and sodic or low organic matter soils. In India, presently about 1.6 million ha is receiving $5 \mathrm{~kg} \mathrm{Zn} \mathrm{ha}^{-1} \mathrm{yr}^{-1}$. With current removal pattern the $\mathrm{Zn}$-deficiency is likely to increase from the present level of 50 to $63 \%$ in
2025 in India (Singh et al., 2010). A widespread Zn-deficiency in Gangetic alluvium plains of West Bengal has been identified by analyzing 6,547 soil samples from which $36 \%$ samples receded very high deficit in available $\mathrm{Zn}$ (Singh, 2007).

Role of $\mathrm{Zn}$ in potato plants: Raulin in 1869 first identified the biological role of $\mathrm{Zn}$, who observed that common bread mould (Aspergillus niger) did not grow due to lack of $\mathrm{Zn}$. Consequently, $\mathrm{Zn}$ was identified as a ubiquitous component of both animal and plant tissue. This observation stimulated $\mathrm{Zn}$ research in crops and leads to the establishment of the essentiality of $\mathrm{Zn}$ in plant nutrition. Presently, zinc deficiency is accepted as one of the most common micronutrient deficiencies and has been increasing significantly in the crop production system. During the early part of $20^{\text {th }}$ century, the agricultural significance of $\mathrm{Zn}$ was recognized, but till late 1960's the specific role for $Z n$ in plants was not identified. Since then a series of $Z n$ -containing enzymes have been identified and significant progress has been made in determining the chemical form and physiological effects of $\mathrm{Zn}$ deficiency in plants. Though the precise mode of action of $\mathrm{Zn}$ in enzymes is still not fully understood, the involvement of $\mathrm{Zn}$ in the activity of various enzymes would indicate that it has profound effects on normal plant metabolism. Generally, $\mathrm{Zn}$ deficiency severely causes an interruption in the metabolism of carbohydrates, proteins, auxin, and reproductive process.

Different role of $\mathrm{Zn}$ in various processes in potato plants has been discussed below.

Carbohydrate metabolism: The specific effect of $\mathrm{Zn}$ nutrition on photosynthesis and sugar transformations confirms the involvement of $\mathrm{Zn}$ in carbohydrate metabolism. Generally, Zn status does not affect respiration in plants.

Photosynthesis: Depending on plant species and extent of deficiency, Zn deficiency causes 50-70\% reduction in net photosynthesis. Several mechanisms can contribute to this reduction as carbonic anhydrase (CA) activity, ribulose 1,5-bisphosphate carboxylase (RuBPC) activity, stabilizing carbamate formation, maintaining chlorophyll content and chloroplast structure of leaf.

Sucrose and starch formation: $\mathrm{Zn}$ deficiency greatly depresses the activity of aldolase in plant tissue, which then impairs the conversion of fructose 1-6-diphosphate to its subsequent compounds. Zn may play a role in the metabolism of starch.

Protein metabolism: General, Zn-deficient plant exhibited dramatic reduction in the amount of protein content, while the composition remains almost unchanged. Cakmak et al. (1989) reported that the concentration of free amino acids in $\mathrm{Zn}$ deficient bean leaves, measured by HPLC is increased by a factor of 6.5 , decreased to $5.1,2.7$, and 1.4 after a resupply of $\mathrm{Zn}$ to deficient plants 
Sarkar, S. et al. / J. Appl. \& Nat. Sci. 10 (3): 1037 - 1045 (2018)

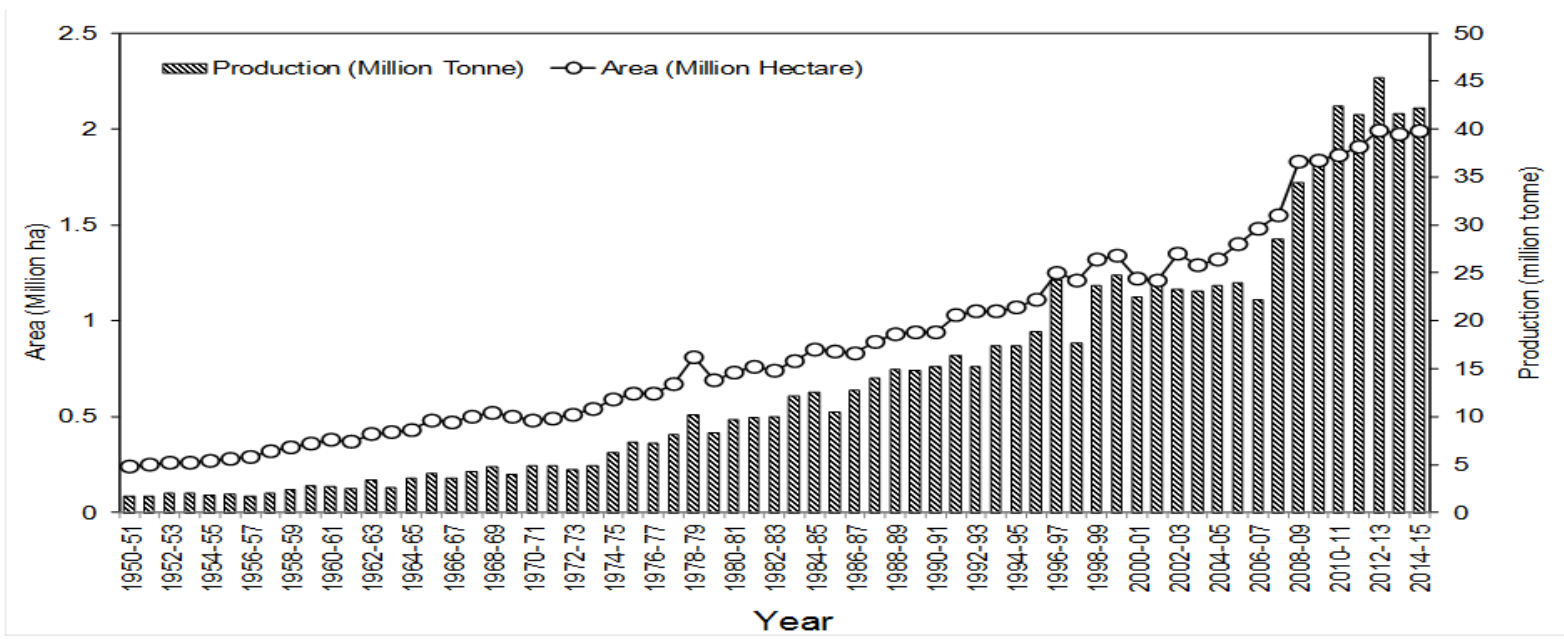

Fig. 1. Trend in production and area of potato in India during last 50 years (Source: INDIASTAT, 2015).

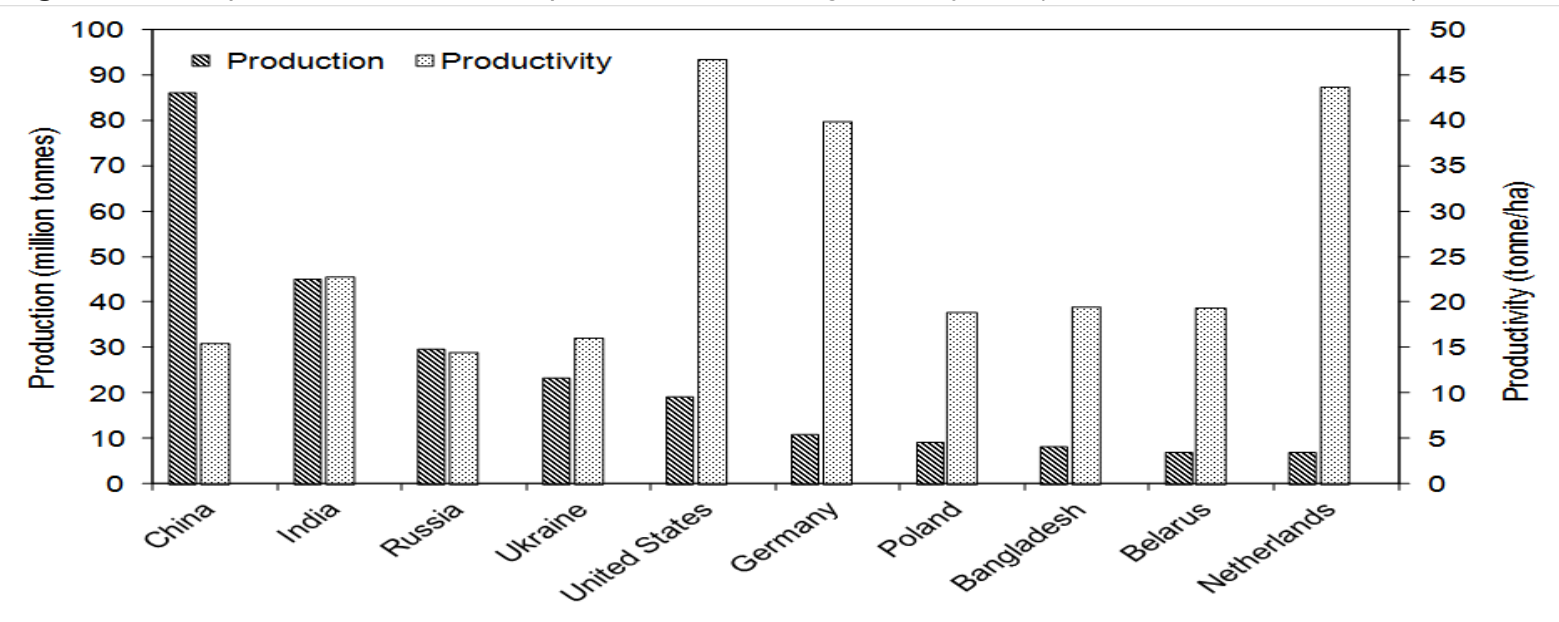

Fig. 2. Major potato growing countries in the world with their productivity (Source: FAO Stat, 2015).

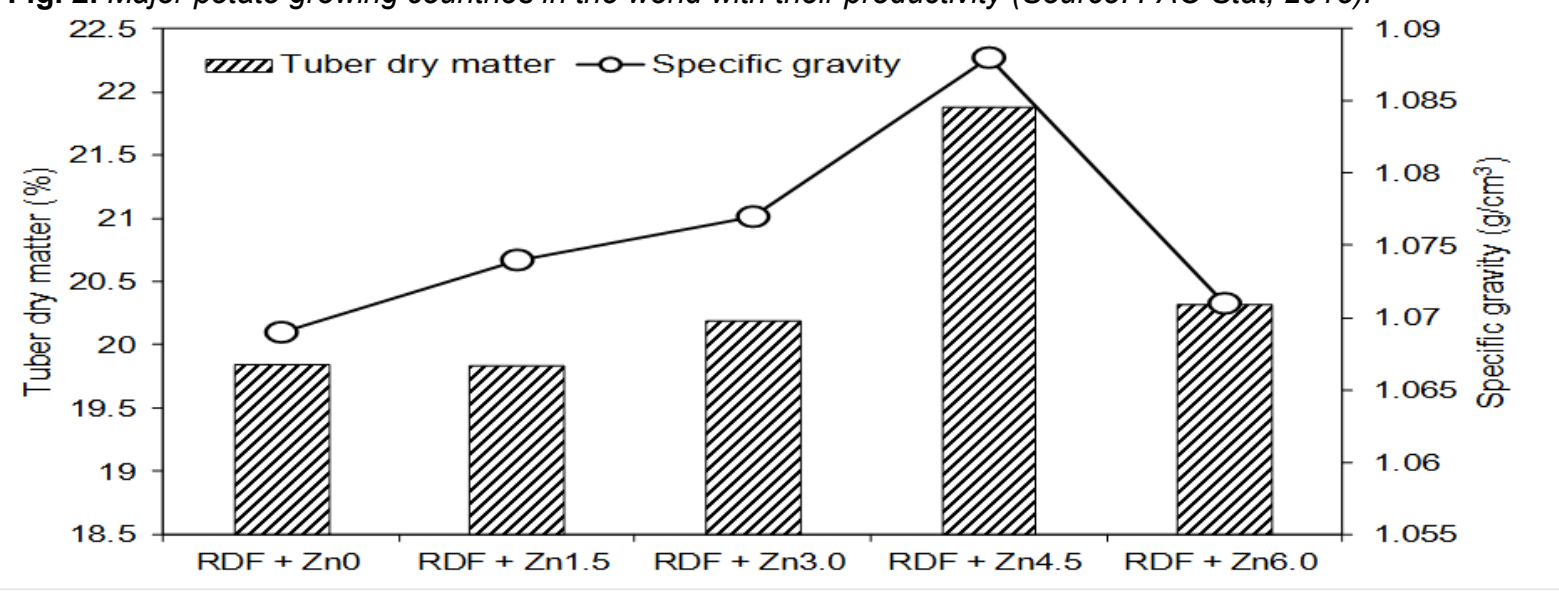

Fertilizer treatment

Fig. 3. Effect of Zn-fertilizer levels on tuber specific gravity and dry matter content of potato (Source: Banerjee et al., 2015).

for $24 \mathrm{~h}, 48 \mathrm{~h}$, and $72 \mathrm{~h}$, respectively compared with control plants.

Membrane integrity: The evidence of $\mathrm{Zn}$ involvement in membranes of higher plants has been demonstrated indirectly. Using root exudates as an indicator of root plasma membrane permeabil- ity, Welch et al. (1982) found greater leakage of ${ }^{32} \mathrm{P}$ from roots of $\mathrm{Zn}$-deficient wheat than from $\mathrm{Zn}$ adequate roots.

Auxin metabolism: $\mathrm{Zn}$ played a key role for maintaining auxin in an active state and that enhanced oxidation caused the decreased indole acetic acid 
Table 1. Zinc containing fertilizers.

\begin{tabular}{|c|c|c|}
\hline Compound & Formula & Zinc content (\%) \\
\hline \multicolumn{3}{|l|}{ Inorganic Compounds } \\
\hline Zinc sulphate monohydrate & $\mathrm{ZnSO}_{4} \cdot \mathrm{H}_{2} \mathrm{O}$ & 36 \\
\hline Zinc sulphate heptahydrate & $\mathrm{ZnSO}_{4} \cdot 7 \mathrm{H}_{2} \mathrm{O}$ & 22 \\
\hline Zinc oxysulphate & $\mathrm{ZnO}_{\mathrm{ZnSO}}$ & $20-50$ \\
\hline Basic zinc sulphate & $\mathrm{ZnSO}_{4} \cdot 4 \mathrm{Zn}(\mathrm{OH})_{2}$ & 55 \\
\hline Zinc oxide & $\mathrm{ZnO}$ & $50-80$ \\
\hline Zinc carbonate & $\mathrm{ZnCO}_{3}$ & $50-56$ \\
\hline Zinc chloride & $\mathrm{ZnCl}_{2}$ & 50 \\
\hline Zinc nitrate & $\mathrm{Zn}\left(\mathrm{NO}_{3}\right)_{2} \cdot 3 \mathrm{H}_{2} \mathrm{O}$ & 23 \\
\hline Zinc phosphate & $\mathrm{Zn}_{3}\left(\mathrm{PO}_{4}\right)_{2}$ & 50 \\
\hline Zinc frits & Fritted glass & $10-30$ \\
\hline Ammoniated zinc & $\mathrm{Zn}\left(\mathrm{NH}_{3}\right)_{4} \mathrm{SO}_{4}$ & 10 \\
\hline \multicolumn{3}{|l|}{ Organic Compounds } \\
\hline Disodium zinc EDTA & $\mathrm{Na}_{2} \mathrm{ZnEDTA}$ & $8-14$ \\
\hline Sodium zinc HEDTA & NaZnHEDTA & $6-10$ \\
\hline Sodium zinc EDTA & NaZnEDTA & $9-13$ \\
\hline Zinc polyflavonoid & -- & $5-10$ \\
\hline Zinc lignosulphonate & -- & $5-8$ \\
\hline
\end{tabular}

Source: Das (2007)

Table 2. Germination, yield and economics of potato (cv. Kufri Jyoti) as influenced by different Zn levels.

\begin{tabular}{|c|c|c|c|c|c|}
\hline $\begin{array}{l}\text { Zinc levels } \\
\left(\mathrm{kg} \mathrm{ha}^{-1}\right)\end{array}$ & $\begin{array}{l}\text { Germination } \\
\%\end{array}$ & $\begin{array}{l}\text { Total tuber } \\
\text { yield }\left(\mathrm{t} \mathrm{ha}^{-1}\right)\end{array}$ & $\begin{array}{l}\text { Average tuber number } \\
\left(\times 10^{5} \mathrm{ha}^{-1}\right)\end{array}$ & $\begin{array}{l}\text { Net return } \\
\left(\text { Rs. } \text { ha }^{-1}\right)\end{array}$ & B:C ratio \\
\hline $\mathrm{RDF}+\mathrm{Zn}_{0}$ & $97.5^{\mathrm{a}}$ & $25.98^{\mathrm{d}}$ & $316.3^{\mathrm{c}}$ & 59266 & 1.61 \\
\hline $\mathrm{RDF}+\mathrm{Zn}_{1.5}$ & $97.5^{\mathrm{a}}$ & $26.54^{\mathrm{b}}$ & $325.3^{b}$ & 61698 & 1.63 \\
\hline $\mathrm{RDF}+\mathrm{Zn}_{3.0}$ & $98.3^{\mathrm{a}}$ & $27.84^{\mathrm{a}}$ & $333.5^{\mathrm{a}}$ & 68574 & 1.70 \\
\hline $\mathrm{RDF}+\mathrm{Zn}_{4.5}$ & $100.0^{a}$ & $27.93^{\mathrm{a}}$ & $342.4^{a}$ & 68181 & 1.69 \\
\hline $\mathrm{RDF}+\mathrm{Zn}_{6.0}$ & $100.0^{\mathrm{a}}$ & $26.06^{\mathrm{C}}$ & $309.4^{d}$ & 56034 & 1.56 \\
\hline
\end{tabular}

RDF of NPK i.e. $200: 150: 150 \mathrm{~kg} / \mathrm{ha}$; Means followed by a different letter are significantly different at $p \leq 0.05$ by Duncan's multiple range tests (Source: Banerjee et al., 2015).

Table 3. Response of potato to Zn fertilizer in different soils of India.

\begin{tabular}{|c|c|c|c|c|}
\hline \multirow[b]{2}{*}{ Soil group } & \multicolumn{2}{|c|}{ Number of experiments } & \multicolumn{2}{|c|}{ Response (t ha ${ }^{-1}$ ) } \\
\hline & Total & Response $\left(>10 \mathrm{q} \mathrm{ha}^{-1}\right)$ & Range & Mean \\
\hline Alluvial soils & 15 & 9 & $1.1-6.5$ & 3.1 \\
\hline Hill soils & 11 & 7 & $1.0-7.9$ & 3.4 \\
\hline Black soils & 8 & 6 & $1.0-4.5$ & 2.6 \\
\hline Red and laterite soils & 7 & 5 & $1.1-3.4$ & 2.4 \\
\hline
\end{tabular}

Source: Grewal and Trehan (1990)

(IAA) level.

Reproduction: Flowering and seed production are known to be severely depressed by $\mathrm{Zn}$ deficiency in beans, peas, and other plants ( $\mathrm{Hu}$ and Sparks, 1990). Lower seed production under Zn deficiency can be attributed to (i) enhanced formation of abscisic acid in the plant, causing premature abscission of leaves and flower buds; (ii) disruption of the development and physiology of anthers and pollen grains.

Defence mechanisms: Zn plays an important function to prevent disease pest incidence in higher plants by improving their defence mechanism (Graham, 1983). Dipping of tuber in $0.05 \%$ $\mathrm{ZnSO}_{4}+1.0 \%$ acetic acid reduces the indices of black-scurf of potato from 97 to $12 \%$ (Somani, 1986).

Deficiency symptoms of $\mathrm{Zn}$ in potato plants: With the increase of cropping intensity, growing of HYVs and minimum or no use of organic manures lead to deficiency of micronutrients especially $\mathrm{Zn}$ in different potato growing soil of India. Now, it has got the primary importance to supplement the micronutrient directly through soil application or spraying on plants or seed treatment methods in order to overcome its deficiency.

Deficiency symptoms of $\mathrm{Zn}$ in potato have been listed below.

- Retards photosynthesis and nitrogen metabolism

- Deficient plant show severe stunting and bronzing or yellowing of the foliage, usually around the leaf margins, starting from the tips.

- Youngest leaves are cupped upward and rolled to such an extent that terminal growth resembles that fern (Fern leaf symptom).

- Leaves of affected plants are smaller and their upper internodes are shorter (little leaf symptom). 
Sarkar, S. et al. / J. Appl. \& Nat. Sci. 10 (3): 1037 - 1045 (2018)

Table 4. Zn uptake and Zn-use efficiency by potato cv. Kufri Jyoti as affected by different Zn levels (values are pooled data of 2013-14 and 2014-15).

\begin{tabular}{lccc}
\hline Treatments & $\mathbf{Z n}$ uptake in tuber $\left(\mathbf{k g ~ h a}^{-\mathbf{1}}\right)$ & $\mathbf{Z n}$ uptake in haulm $\left.\mathbf{( k g ~ h a} \mathbf{- 1}^{-1}\right)$ & Total Zn uptake (kg ha $\left.^{-1}\right)$ \\
\hline $\mathrm{RDF}+\mathrm{Zn}_{0}$ & $31.65^{\mathrm{e}}$ & $102.69^{\mathrm{e}}$ & $134.34^{\mathrm{e}}$ \\
$\mathrm{RDF}+\mathrm{Zn}_{1.5}$ & $34.07^{\mathrm{d}}$ & $126.01^{\mathrm{d}}$ & $160.08^{\mathrm{d}}$ \\
$\mathrm{RDF}+\mathrm{Zn}_{3.0}$ & $37.10^{\mathrm{c}}$ & $140.64^{\mathrm{c}}$ & $177.73^{\mathrm{c}}$ \\
$\mathrm{RDF}+\mathrm{Zn}_{4.5}$ & $41.03^{\mathrm{b}}$ & $154.00^{\mathrm{b}}$ & $195.03^{\mathrm{b}}$ \\
$\mathrm{RDF}+\mathrm{Zn}_{6.0}$ & $43.20^{\mathrm{a}}$ & $163.68^{\mathrm{a}}$ & $206.88^{\mathrm{a}}$ \\
\hline
\end{tabular}

RDF/recommended dose of fertilizer, $200: 150: 150 \mathrm{~kg} \mathrm{ha}^{-1}$, Means followed by a different letter are significantly different at $p \leq 0.05$ (otherwise statistically at par); NS, Non-significant (Source: Banerjee et al., 2016)

Table 5. Quality parameters of potato (cv. Kufri Jyoti) as influenced by different Zn levels.

\begin{tabular}{|c|c|c|c|c|}
\hline Zinc levels (kg ha ${ }^{-1}$ ) & TSS ('Brix) & Total Acidity (\%) & Ascorbic Acid (mg $100 \mathrm{~g}^{-1}$ ) & 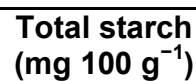 \\
\hline $\mathrm{RDF}+\mathrm{Zn}_{0}$ & $5.90^{a}$ & $8.25^{\mathrm{a}}$ & $19.75^{\mathrm{a}}$ & $56.76^{\mathrm{c}}$ \\
\hline $\mathrm{RDF}+\mathrm{Zn}_{1.5}$ & $5.90^{a}$ & $8.25^{a}$ & $20.25^{\mathrm{a}}$ & $56.6^{\mathrm{c}}$ \\
\hline $\mathrm{RDF}+\mathrm{Zn}_{3.0}$ & $5.92^{\mathrm{a}}$ & $8.37^{a}$ & $19.25^{\mathrm{a}}$ & $57.4^{\mathrm{b}}$ \\
\hline $\mathrm{RDF}+\mathrm{Zn}_{4.5}$ & $6.10^{a}$ & $8.12^{a}$ & $19.50^{\mathrm{a}}$ & $57.73^{\mathrm{ab}}$ \\
\hline $\mathrm{RDF}+\mathrm{Zn}_{6.0}$ & $6.42^{\mathrm{a}}$ & $8.97^{\mathrm{a}}$ & $19.25^{\mathrm{a}}$ & $58.05^{\mathrm{a}}$ \\
\hline
\end{tabular}

RDF of NPK i.e. $200: 150: 150 \mathrm{~kg} \mathrm{ha}^{-1}$; Means followed by a different letter are significantly different at $p \leq 0.05$ by Duncan's multiple range tests (Source: Banerjee et al., 2017).

- Delayed maturity as a result of prolonged growth periods, ultimately resulting into low yield and poor quality of tuber.

Strategies for increasing $\mathrm{Zn}$ content in crops: The $\mathrm{Zn}$ content in crops can be improved by two ways, either by breeding new cultivars that absorb and transmit more $\mathrm{Zn}$ to grains (Bio-fortification) or by fertilizing crops with Zn (Ferti-fortification).

There are a number of programmes for biofortification, such as Harvest-Plus Consortium of the CGIAR Challenge Programme, The Global Rice Project, African fortified Sorghum Project, Bio-Cassava Plus and Bio-fortification of Banana with a goal of developing nutrient-rich crop varieties (Prasad et al., 2012). The ability of a plant to grow and yield under $\mathrm{Zn}$ stress in soil is known as high $\mathrm{Zn}$ efficiency. This could be achieved by a crop due to possession of either one or all of the following characters- a better root system, higher synthesis and release of iron and $\mathrm{Zn}$ mobilizing phyto-siderophores by the roots, affinity of the root uptake system, translocation in plants and capacity to utilize absorbed $\mathrm{Zn}$. Moreover, micro-nutrient uptake by plants is also influenced by physical, chemical and biological properties of soil (Prasad, 2012).

Ferti-fortification: The term 'Ferti-fortification' was coined by Prasad (2012) which refers fertilizing crops with micronutrients. It gives immediate results and in general, goes well along with an increase in yield. The $\mathrm{Zn}$ deficiency is found in $49 \%$ of Indian soils, wherein response of most crops to $\mathrm{Zn}$ fertilization has been reported (Shukla and Behera, 2012); however, the attention on $\mathrm{Zn}$ concentration in grains did not receive much attention until the bio-fortification of grains and fruits became popular.

Potato: As potential option for $\mathrm{Zn}$ ferti- fortification: Zinc plays a very important role in increasing the production as well as quality. Results of IZA-MOA joint project revealed that the application of $\mathrm{ZnSO}_{4}, \mathrm{H}_{2} \mathrm{O} @ 15 \mathrm{~kg} \mathrm{ha}^{-1}$ in potato resulted highest percent of yield increase (upto $25 \%$ ) compared to other fruit and vegetable crops. Potato is one of the highest $\mathrm{Zn}$ accumulator compared to the rice where rice can accumulate upto 18.6 to $28.1 \mathrm{mg} \mathrm{Zn} \mathrm{kg}^{-1}$ of dry matter where most of the $\mathrm{Zn}$ has removed during processing (milling, polishing and cooking) (Hazra et al., 2015). In contradictory to rice, $\mathrm{Zn}$ accumulation in potato taken places in the tuber (vegetative portion) which was not removed during possessing. People need up to $15 \mathrm{mg}$ of zinc per day, as recommended by World Health Organization (WHO). Most of the $\mathrm{Zn}$ ferti-fortification programme carried out through the world, showed that $\mathrm{Zn}$ loading in potato through foliar as well as soil-applied $\mathrm{Zn}$, increases $\mathrm{Zn}$ concentration in potato tuber upto 34 times (30-40 mg Zn kg-1 of dry matter) which is quite higher than most of the commonly known fruit crops (White et al., 2012; Murmu et al., 2014). Understanding these findings, Zn-fortified potato can be a potential option to reduce $\mathrm{Zn}$ driven malnutrition among the developing countries.

Critical values of $\mathrm{Zn}$ in soil and potato plants: Critical levels of $\mathrm{Zn}$ in potato growing soils of West Bengal (India) for soil as well as potato shoot and tuber were estimated by Dhar (2011) in a green house experiment where potato was grown at four levels of $\mathrm{Zn}\left(0,5,10\right.$ and $\left.20 \mathrm{~kg} \mathrm{ha}^{-1}\right)$. For this purpose, 21 soil samples were collected from various locations of the different districts like Coochbehar, Jalpaiguri, Murshidabad, Nadia, Hooghly and Midnapore of West Bengal (India). For available Zn status, soils were extracted with DTPA. Critical limits of $\mathrm{Zn}$ in soils, potato shoot and potato tuber were determined through the graphical method 
proposed by Cate and Nelson (1971). In this graphical method, for determination of critical limit of $\mathrm{Zn}$ in soils, potato shoot and potato tuber, Bray's percent yield (BPY) was calculated using the following formula:

$$
B Y P=\frac{\text { Yield without nutrient }}{\text { Yield with optimum nutrient }} \times 100
$$

Results showed that critical level of $\mathrm{Zn}$ in soils for potato plant (shoot + tuber) is approximately 0.59 $\mathrm{mg} \mathrm{kg}^{-1}$. In this respect, we can say that $\mathrm{Zn}$ concentration below $0.59 \mathrm{mg} \mathrm{kg}^{-1}$ will respond readily to its application. Zn concentration above it may reduce the growth of potato plant and may be toxic for that particular plant. Results also showed that the critical limits of $\mathrm{Zn}$ in potato shoot and tuber was 45 and $10 \mathrm{mg} \mathrm{kg}^{-1}$, respectively.

Management options for zinc: To meet the demand of potato crop and ameliorate the $\mathrm{Zn}$ deficiency in soils, the application of $\mathrm{Zn}$-fertilizer is highly profitable. Moreover, the choice of an appropriate $\mathrm{Zn}$-fertilizer with proper dose and application method is very much important (Das, 2011)

Fertilizer sources: Different sources of zinc fertilizers are inorganic compounds, synthetic chelates and natural organic complexes; they vary considerably with respect to zinc content, effectiveness for crops on different types of soils and price (Table 1). However, sulphate salt is the common source of $\mathrm{Zn}$. Zinc sulphate monohydrate and zinc sulphate heptahydrate are the most widely marketed used $\mathrm{Zn}$ fertilizer in India.

- Zinc sulphate, zinc oxide, zinc carbonate, zinc nitrate, and zinc chloride are some of the inorganic sources of $\mathrm{Zn}$. Worldwide the most commonly used zinc fertilizer source is zinc sulphate, both crystalline monohydrate and heptahydrate forms.

- Synthetic chelates, a form of complex micronutrients, are prepared by mixing a chelating agent such as Ethylene Diamine Tetra-acetic Acid (EDTA) with a metal ion. The most commonly used chelated source of zinc is disodium salt of $\mathrm{Zn}$-EDTA ( $\left.\mathrm{Na}_{2} \mathrm{Zn}-\mathrm{EDTA}\right)$. Synthetic chelates, with their high stability, are highly suitable for mixing with concentrated fertilizer solutions for soil, fertigation and hydroponic applications. They are also suitable for foliar feeding, but repeated applications may be required under moderate to severe zinc deficient conditions because of their relatively low zinc content.

- Natural organic complexes are manufactured by reacting zinc salts with citrates or with organic by-products from paper pulp manufacture such as lignosulphonates, phenols and polyflavonoids. Generally, they are cheaper than synthetic chelates.

Application method: Under filed conditions, several methods of $\mathrm{Zn}$ application have been evaluat- ed to overcome Zn-deficiency. Usually three methods are followed for $\mathrm{Zn}$ fertilization in potato.

Soil application: The deficiency of $\mathrm{Zn}$ may be corrected by soil application of inorganic fertilizer like zinc sulphate @ $25 \mathrm{~kg} \mathrm{ha}^{-1}$. Soil application through broadcasting followed by mixing, drilling, band placement and top dressing have been found to be effective (Das, 2011). The application of $\mathrm{Zn}$ in soils not only increased the yield of crops, but also decreased the concentration of cadmium (Cd) in soils, thereby decreased the content and uptake of $\mathrm{Cd}$ by the plants.

Foliar application: Foliar sprays with $0.02 \%$ zinc solution (200 g 100 litres $^{-1}$ of water) on the standing crop at 40 and 60 DAP in the plains, and 60 and 80 DAP in hills have been found effective. Foliar spray should be avoided between 11.00 am to $3.00 \mathrm{pm}$ to prevent scorching of leaves (Sharma, 2002).

Seed treatment: In this method, seed tubers are soaked in $0.05 \%$ zinc sulphate solution ( $50 \mathrm{~g}$ per 100 litres of water) for 3 hours. The soaked tubers are dried in shade for 24 hours and then planted in the field (Mondal et al., 2015).

A number of studies have been conducted to compare the effectiveness of different methods and it has been found that all the three methods are equally effective for increasing the tuber yield of potato (Mondal et al., 2015). Further, the application of $\mathrm{Zn}$ either as soil application or foliar spray triggers several metabolic pathways in the plants like translocation of $\mathrm{Zn}$ within the plant, enzyme activities etc. which finally influences growth and yield of crops (Das, 2011).

\section{Zn fertilization effects on potato}

Growth of potato as affected by $\mathrm{Zn}$ fertilization: Growth of potato plant is greatly influenced by micronutrient application like zinc. Kumar et al. (2008a) recorded significant influence by the zinc on the growth characters of potato and obtained higher values of plant height, $\mathrm{LAl}$ and dry matter with tuber dipping in $0.05 \% \mathrm{ZnSO}_{4}$ solution for 3 hrs one day prior to sowing. The reason is zinc plays a key role in plant metabolism, particularly in auxin synthesis which is an essentially required for growth and development of a crop. However, in an earlier study, Banerjee et al. (2015) did not find any significant effect of $\mathrm{Zn}$ fertilization on plant height, number of compound of compound plant $^{-1}$ as well as the number of haulms plant ${ }^{-1}$ at Kalyani region of West Bengal. This result corroborates to that of Bari et al. (2001) and Islam et al. (1982) who demonstrated non-significant of $\mathrm{Zn}$ fertilization on plant growth of potato. Banerjee et al. (2016) also reported that $\mathrm{Zn}$ fertilization increased leaf area index of potato during early stage of growth only which might be due to higher vegetative growth, as resulted from higher rate of nitrogen metabolism and photosynthetic activity with Zn fertilization (Paygozar et al., 2009). Ravi et 
al. (2010) also supported the increase of LAI by $\mathrm{Zn}$ fertilization in potato and thereby increase in amount of dry matter accumulation and economic yield. The omission of $\mathrm{Zn}$ causes significant reduction in dry matter (12.2\%) of potato cv. Kufri Bahar (Singh et al., 2014). Al-Jobori and AlHadithy (2014) found higher dry matter content in potato plant with chelated-Zn fertilization. Moreover, increased tuber dry matter percent with $\mathrm{Zn}$ fertilization was obtained as a result of greater tuber size and higher starch accumulation.

Yield of potato as affected by $\mathrm{Zn}$ fertilization: The positive influences of $\mathrm{Zn}$ fertilization in augmenting quantitative (yield) and qualitative parameters of potato crop were earlier indicated by several investigators (Mousavi et al., 2007). Zinc fertilization in potato resulted significant increase in tuber number, tuber weight, tuber yield, other qualitative traits and post-harvest indices. The increased tuber yield of potato might be attributed to the beneficial effect on tuberization as a result of $\mathrm{Zn}$ application (Mondal et al., 2015) and $\mathrm{Zn}$ content in tubers (Singh et al., 2009; Singh et al., 2010). Banerjee et al. (2016) recorded highest potato yield $7.51 \%$ along with total tuber number, net return and $\mathrm{B}: \mathrm{C}$ ratio with $\mathrm{RDF}+4.5 \mathrm{~kg} \mathrm{Zn}$ $\mathrm{ha}^{-1}$, respectively over potato fertilized with RDF only (Table 2 ).

In an earlier study, Kumar et al. (2008a) meticulously documented the beneficial effect of $\mathrm{ZnSO}_{4}$ on crop growth, greater synthesis as well as translocation of food material to developing tuber. Their subsequent study proved that $\mathrm{Zn}$ application also helped in increasing the average weight of individual tuber from small to medium and medium to large size (Kumar et al., 2008b). Al-Jobori and AlHadithy (2014) who demonstrated foliar spray of $\mathrm{Zn}$ recorded $10.67 \%$ higher yield over control. Brahmachari et al. (2010) also recorded $9.2 \%$ yield increment with tuber soaking in $0.5 \% \mathrm{ZnSO}_{4}$ solution. All India coordinated study on potato to micronutrient response showed that yield response of potato to applied $\mathrm{Zn}$ fertilizer varies with the soil type, variety, quantity of other major nutrients applied to the soil and finally method of application (Mondal et al., 2015). The extents of response of potato to applied Zn fertilizer in different soils are stated in Table 3 . Zinc application through soil (20 kg ZnSO $\left.\mathrm{ha}^{-1}\right)$, foliar spray (0.02 $\%$ zinc sulphate solution at 40 and 60 days after planting) and soaking of tuber $(0.05 \%$ zinc sulphate solution for three hours) significantly increased the tuber yield of potato (Sharma and Grewal, 1988).

Zn uptake by potato: It was found that the concentration of $\mathrm{Zn}$ in tubers increased with increasing $\mathrm{Zn}$ fertilization upto a certain extent, however, $\mathrm{Zn}$ concentrations in tubers were far below to that of shoot $\mathrm{Zn}$ concentrations (Table 4). The relationship between $\mathrm{Zn}$ application and tuber $\mathrm{Zn}$ concen- tration exhibited a saturation curve, depicting a maximum value of $30 \mathrm{mg} \mathrm{kg}^{-1} \mathrm{DM}$ (White et al., 2012). Poor tuber $\mathrm{Zn}$ concentrations might be accorded to restricted entry of $\mathrm{Zn}$ into leaf cells, or restricted loading of $\mathrm{Zn}$ into the phloem in the shoot. Below this maximum value, tuber $\mathrm{Zn}$ concentrations were greater in crops that had received multiple smaller applications than a single large foliar application of Zn-fertilizer to the plot. Hazra et al. (2012) obtained a result from Hooghly (West Bengal) while studying the effect of $\mathrm{Zn}$ on yield of two popular cultivars i.e. Kufri Jyoti and Kufri Chandramukhi of West Bengal, that $\mathrm{Zn}$ uptake of potato tubers increased with $\mathrm{Zn}$ fertilization in both cultivars of potato and magnitude of increase was higher in case of Kufri Chandramukhi than Kufri Jyoti. In Iran, Mousavi et al. (2007) demonstrated that foliar application of Zn @ 2, 4 and 8 ppt caused considerable increase in tuber Zn concentration, accounting 8, 22 and 23\% more than control, respectively.

Quality of potato as influenced by $\mathrm{Zn}$ fertilization: Zn fertilization has a great impact on the quality parameters of potato. Banerjee et al. (2015) reported that $4.5 \mathrm{~kg} \mathrm{ha}^{-1} \mathrm{Zn}$ fertilization has positive impact on tuber specific gravity as well as dry matter accumulation (Fig. 3). Mousavi et al. (2007) also found $1.9 \%$ increment in potato tuber specific weight with $8 \mathrm{ppm} \mathrm{ZnSO}_{4}$ foliar application. $\mathrm{Zn}$ fertilization may have positive impact on tuber ascorbic acid content as Mondy et al. (1993) find that higher ascorbic acid content in tuber with a high dose of $\mathrm{ZnSO}_{4}\left(112 \mathrm{~kg} \mathrm{ha}^{-1}\right)$, but Banerjee et al. (2015) did not find any significant effect with Zn on tuber ascorbic acid content (Table 5). In the same experiment, Banerjee et al. (2017) found that $\mathrm{Zn}$ fertilization has a little impact on tuber total sugar content but higher amount of starch content which is very important for chipping quality (Table 4). Earlier studies of Dwivedi and Dwivedi (1992) also showed that $10 \mathrm{~kg} \mathrm{ZnSO}_{4} \mathrm{ha}^{-1}$ was adequate to increase the potato tuber yield and starch content. They concluded that starch content in potato tuber was affected not only by $\mathrm{Zn}$-rates but also by the method of $\mathrm{Zn}$ application. In their study, starch content of tuber was significantly affected by soil application $\left(10 \mathrm{~kg} \mathrm{ZnSO} \mathrm{ha}^{-1}\right)$ as well as seed soaking with $\mathrm{Zn}\left(\mathrm{R}^{2}=0.602\right)$. Kumar et al., (2008a) opined that greater accumulation of starch depends on the higher rate of photosynthesis, better translocation of photosynthates from leaves to tubers and subsequent conversion to starch. Therefore, increased starch accumulation in tubers might be due to higher rate of photosynthesis with zinc application. However, Murmu et al. (2014) reported non-significant effect of $\mathrm{ZnSO}_{4}$ application on total sugar content of potato (cv. Kufri Jyoti) upto $10 \mathrm{~kg} \mathrm{ha}^{-1}$. Mondal et al. (2015) had an opinion that omission of $\mathrm{Zn}$ reduced the protein yield when compared with balanced fertili- 
zation plus $\mathrm{Zn}$ owing to reduction in tuber yield. Zinc fertilization interestingly improves the chip colour of potato. This may be due to less production of phenol substances in tuber influenced by $\mathrm{Zn}^{++}$ion thus few chances of enzymatic discolouration of potato chips during frying. Mondy and Chandra (1981) found that Zn fertilization significantly reduce the total phenol content of tuber thus improves chip colour while frying. Kumar et al. (2008a) also found similar results with 'Kufri Chipsona-1' cultivar where three times $0.2 \%$ foliar sprays with $\mathrm{ZnSO}_{4}$ significantly improved chip colour over control.

\section{Conclusion}

Since most of the Indian soils are deficient in $\mathrm{Zn}$ (50\% soils of India and $34 \%$ of West Bengal), micronutrient management (especially $\mathrm{Zn}$ ) has received greater attention in potato production system to combat wide spared $\mathrm{Zn}$ deficiency. Potato responds well to the applied $Z n$ fertilizer (3-10 $\left.\mathrm{kg} \mathrm{Zn} \mathrm{ha}{ }^{-1}\right)$. Zn plays an important role for growth, productivity and post-harvest quality of potato. Znfortified potato can be a potential option for mitigating wide spread $\mathrm{Zn}$-driven malnutrition in Indian subcontinent.

\section{REFERENCES}

1. Al-Jobori, K.M. and Al-Hadithy, S.A. (2014). Response of Potato (Solanum tuberosum) to Foliar Application of Iron, Manganese, Copper and Zinc. Int. J. Agric. Crop Sci., 7(7): 358-363.

2. Banerjee, H., Sarkar, S., Deb, P., Chakbaborty, I., Ray, K. and Sau, S. (2017). Zinc fertilization in potato: A physiological and bio-chemical study. Int. J. Plant and Soil Sci. 16(2): 1-13.

3. Banerjee, H., Sarkar, S., Deb, P., Dutta, S.K., Ray, K., Rana, L. and Majumdar. K. (2016). Impact of zinc fertilization on potato (Solanum tuberosum L.) yield, zinc use efficiency, quality and economics in entisol of West Bengal. J. Indian Soc. Soil Sci., 64(2): 176-182.

4. Banerjee, H., Sarkar, S., Ray, K., Rana, L., Deb, P., Chakraborty, A., Chakraborty, I., Bhattacharya, A. and Dollui, S. (2015). Response of potato (Solanum tuberosum L.) to zinc fertilization in trans-Gangetic plains of West Bengal. In Extended Summery of National Symposium on Sustainable Agriculture for Food Security and Better Environment". December 17-18, 2015. Department of Agronomy, Bidhan Chandra Krishi Viswavidyalaya, Mohanpur-741252, Nadia, West Bengal

5. Bari, M.S., Rabbani, M.G., Rahman, M.S., Islam, M. J., and Hoque, A.T.M.R. (2001). Effect of zinc, boron, sulphur and magnesium on the growth and yield of potato. Pak. J. Biol. Sci., 4(9): 1090-1093.

6. Birch, P.R.J., Bryan, G, Fenton, B., Gilroy, E.M., Hein, I., Jones, J.T., Prashar, A., Taylor, M.A., Torrance, L. and Toth, I.K. (2012). Crops that feed the world 8: Potato: are the trends of increased global production sustainable? Food Security, 4: 477-508.

7. Brahmachari, K., Kundu, R., Roychoudhury, S., and Sounda, G. (2010). Effects of different methods of application of zinc on productivity and quality of pota- to under coastal saline soil of West Bengal. Indian Agriculturist, 54(3 \& 4): 143-146.

8. Cakmak, I, Marschner, H. and Bangerth, F. (1989). Effects of zinc nutritional status on growth, protein metabolism and levels of indole-3-acetic acid and other phytohormones in bean (Phaseolus vulgaris $\mathrm{L}$.) J. Exp. Bot., 40: 405-412.

9. Cate, R.B. and Nelson, L.A. 1971. A simple statistical procedure for partitioning soil test correlation data into two classes. Soil Sci. Soc. Am. J., 35(4): 658-660.

10.Das, D.K. (2011). Copper and zinc: In Micronutrients: Their behaviour in soils and plants. Kalyani Publishers, New Delhi, pp. 54-150.

11.Dhar, D. (2011). Studies on zinc nutrition in potato growing soil of West Bengal. Ph.D. Thesis, Bidhan Chandra Krishi Viswavidyalaya, Mohanpur, West Bengal, India.

12.Dwivedi, G.K. and Dwivedi, M. (1992). Efficacy of different modes of application of copper, zinc and boron to potato. Ann. Agricultural Res., 13(1): 1-6.

13.FAO Stat. (2015). Food and Agriculture Organisation of the United Nations, Land Resources. Retrieved December, 152015 from http://www.fao.org/nr/land/ databasesinformationsystems/en/.

14.Graham, R.D. (1983). Effects of nutrient stress on susceptibility of plants to disease with particular reference to the trace elements. Adv. Bot. Res., 10: 221-276.

15. Hazra, G.C., Saha, B. and Mandal, B. (2012). Micronutrient Research in West Bengal. Bidhan Chandra Krishi Viswavidyalaya, Mohanpur, West Bengal, India, pp. 1-73.

16. Hazra, G.C., Saha, B., Saha, S., Dasgupta, S., Adhikari, B. and Mandal, B. 2015. Screening of rice cultivars for their zinc bio-fortification Potential in Inceptisols. J. Indian Soc. Soil Sci., 63(3): 347-357.

17. Hu, H. and Sparks, D. (1990). Zinc deficiency inhibits reproductive development in 'Stuart' pecan. Hort. Science, 25: 1392-1396.

18.INDIASTAT. (2015). Ministry of Agriculture, GOI. Retrieved June, 012015 from http:// www.indiastat.com

19.Islam, M.S., Razia, S. and Hossain, K.M. (1982). Effect of different fertilizer elements on the growth and yield of potato. Bangladesh J. Agric., 7: 53-56.

20.Kumar, P., Pandey, S.K., Singh, S.V., Singh, B.P., Rawal, S. and Kumar, D. (2008a). Evaluation of nutrient management options for potato processing cultivars. Pot. J., 35(1 \& 2): 46-52.

21.Kumar, V., Vyakarnahal, B. S., Basavaraj, N., Kulkarni, S. and Shekhargouda, M. (2008b). Influence of micronutrients on growth and yield of potato (Solanum tuberosum) cultivars. Indian J. Agric. Sci., 78(9): 752-756.

22.Mondal, S.S., Chettri, S., Sarkar, S. and Monda, T.K. (1993). Effect of sulphur bearing fertilizer on potato. J. Indian Pot. Asso., 20: 139-143.

23.Mondal, S.S., Patra, B.C. and Banerjee, H. (2015). Micronutrient management. In: Advances in Potato Cultivation Technology. Kalyani Publishers, New Delhi, pp. 115-121.

24.Mondy, N.I. and Chandra, S. (1981). Effect of zinc fertilization on yield, enzymatic discoloration, phenolic and nitrogenous constituents of potato tubers. J. Food Sci., 46(6): 1878-1880.

25.Mondy, N.I., Chandra, S. and Munshi, C.B. (1993). 
Zinc fertilization increases ascorbic acid and mineral contents of potatoes. J. Food Sci., 58(6): 1375-1377. 26.Mousavi, S. R., Mohammad, G. and Goudarz, A. (2007). Effect of zinc and manganese foliar application on yield, quality and enrichment on potato (Solanum tuberosum L.). Asian J. Plant Sci., 6(8): 1256-1260.

27.Murmu, S., Saha, S., Saha, B. and Hazra, G.C. (2014). Influences on Zn and B on the yield and nutrition of two widely grown potato cultivars (Solanum tuberosum L.). Ann. Biol., 30(1): 37-41.

28.Nene, Y.L. 1966. Symptoms, cause and control of Khaira disease of paddy. Bull. Indian Psychopathological Soc., 3: 97-101.

29.Paygozar, Y., Ghanbari, A., Heydari, M. and Tavassoli, A. (2009). Effect of foliar application of micronutrients on qualitative and quantitative characteristics of pearl millet (Pennisetum glacum) under drought stress. J. Agric. Sci., 3(10): 67-79.

30.Prasad, R., Shivay, Y.S. and Kumar, D. (2012). Biofortification/ fertifortification of rice (Oryza sativa) and wheat (Triticum aestivum) for ameliorating zinc malnutrition of humans and animals in India. Indian J. Agron., 57(3 Special Issues): 195-198.

31.Ravi, S., Channal, H.T., Hebsur, N.S. and Dharmatti, P. R. (2010). Effect of sulphur, zinc and iron nutrition on growth, yield, nutrient uptake and quality of safflower (Carthamus tinctorius L.). Karnataka J. Agricultural Sci., 21(3): 382-385.

32.Sharma, R.C. (2002). Potato. Textbook of Field Crop Production (Prasad, R. Tech. Ed.), ICAR, New Delhi, pp. 748-749.

33.Sharma, U.C. and Grewal, J.S. (1988). Relative effectiveness of methods of micro-nutrient application to potato. J. Indian Soc. Soil Sci., 36(1): 128-132.

34.Shukla, A.K. and Behera, S.K. (2012). Micronutrient fertilizers for higher productivity. Indian J. Fertilizers, 8(4): 100-107.

35.Singh, H., Singh, S.P. and Singh, M.P. (2009). Effect of potassium and zinc on tuber yield, quality and nutrient uptake in potato. Ann. Plant and Soil Res., 11 (2): 140-142.

36.Singh, M.V. (2007). Efficiency of seed treatment for ameliorating zinc deficiency in crops. In Proceedings of Zinc Crops Conference, Istanbul, Turkey.

37.Singh, S., Kumar, D., Chandel, B.S. and Singh, V. (2014). Effect of balanced fertilization on yield, nutrients uptake and economics of potato (Solanum tuberosum L.) in alluvial soil. Indian J. Agron., 59(3): 451-454.

38.Singh, S.K., Kumar, D., and Lal, S.S. (2010). Integrated use of crop residues and fertilizers for sustainability of potato (Solanum tuberosum L.) based cropping systems in Bihar. Int. J. Agron. 55(3): 203-208.

39.Somani, A.K. (1986). Non-hazardous chemical control of black scurf of Potato. Indian J. Agric. Sci., 56: 366-369.

40.Struik, P.C., Lommen, W.J.M., Haverkort, A.J. and Storey, R.M.J. (2007). The canon of potato science. Pot. Res., 50(3 \&4): 205-206.

41.Takkar, P.N. (1991). Zinc Deficiency in Indian Soils and Crops. Zinc in Crop Nutrition. International Lead Zinc Research Organization, Inc. and Indian Lead Zinc Information Centre, New Delhi, pp. 55-64.

42.Trehan, S.P and Grewal, J.S. (1981). Comparative efficiency of methods of application of zinc to potato. Indian J. Agric. Sci., 51: 240-243.

43.Welch, R.M., Webb, M.J. and Loneragan, J.F. (1982). Zinc in membrane function and its role in phosphorus toxicity [Crops]. In Plant Nutrition 1982: Proceedings of the Ninth International Plant Nutrition. pp. 710-715.

44.White, P.J., Broadley, M. R., Hammond, J.P., Ramsay, G., Subramanian, N. K., Thompson, J. and Wright, G. (2012). Bio-fortification of potato tubers using foliar zinc-fertilizer. J Hortic. Sci. Biotechnol., 87(2): 123-129. 